\title{
Growth, ammonium excretion, and oxygen consumption of hybrid red tilapia (Oreochromis mossambicus $\times$ Oreochromis aureus) grown in seawater and freshwater
}

\section{Crecimiento, excreción de amonio y consumo de oxígeno de la tilapia híbrida roja (Oreochromis mossambicus $\times$ Oreochromis aureus) cultivada en agua de mar y en agua dulce}

\author{
Fernando Barreto-Curiel ${ }^{1}$, Eduardo Durazo ${ }^{2}$, María Teresa Viana ${ }^{3}$ \\ ${ }^{1}$ Programa de Maestría y Doctorado en Ecología Molecular y Biotecnología, Facultad de Ciencias Marinas, \\ Universidad Autónoma de Baja California (UABC), AP 76, CP 22800, Ensenada, BC, México. \\ 2 Facultad de Ciencias Marinas, UABC, AP 76, CP 22800, Ensenada, BC, México. \\ 3 Instituto de Investigaciones Oceanológicas, UABC, Carretera Tijuana-Ensenada No. 3917, Fraccionamiento \\ Playitas, CP 22860 Ensenada, BC, México.
}

* Corresponding author: E-mail: viana@uabc.edu.mx

\begin{abstract}
In a comparative study using the hybrid tilapia Oreochromis mossambicus $\times$ Oreochromis aureus grown in seawater and freshwater, no significant differences in growth performance (weight gain) and biological indices (e.g., feed conversion efficiency and survival) was observed after 90 days of experimentation. A common feed was formulated to contain $40 \%$ crude protein and $8.5 \%$ crude fat. Fish meal and poultry by-product meal (50:50) were used as a source of protein in the formulation. The study was conducted using recirculation systems and organisms already adapted to seawater and freshwater with an initial weight of $25.0 \pm 0.06 \mathrm{~g}$ and $24.70 \pm 0.32 \mathrm{~g}$, respectively (four replicates per treatment); at the end of the experiment their final weight was $161.80 \pm 12.78 \mathrm{~g}$ and $167.60 \pm 7.29 \mathrm{~g}$, respectively. The thermal growth coefficient was 0.91 and 0.89 (seawater vs freshwater), and there were no significant differences; however, the apparent digestibility of dry matter as well as per nutrient (protein, lipid, and carbohydrate) was significantly higher for the organisms in the seawater treatment. The digestibility could be associated with greater enzymatic activity in the presence of higher ionic strength. The respirometric study indicated that the O:N ratios were similar for organisms reared in seawater and freshwater, with values of 21 and 18, respectively. This indicates that this strain of tilapia uses a mixture of proteins and lipids as energy substrates. We conclude that this strain of tilapia has the potential to adapt and thrive in a marine environment and that its production practices could be expanded.
\end{abstract}

Key words: hybrid tilapia, seawater, growth, O:N ratio, metabolic substrate.

RESUMEN. En un estudio comparativo en el cual se utilizó el híbrido de tilapia Oreochromis mossambicus $\times$ Oreochromis aureus cultivado en agua de mar y en agua dulce no se observaron diferencias significativas en el desempeño como crecimiento en peso e índices biológicos (e.g., conversión alimenticia y supervivencia) después de 90 días de experimentación. Se utilizó un alimento común elaborado en el laboratorio que contenía $40 \%$ de proteína cruda y $8.5 \%$ de grasa cruda. Para la formulación del alimento, se utilizó harina de pescado y harina de subproducto de ave (50:50) como fuente de proteína. El estudio se realizó utilizando sistemas de recirculación y organismos de $25.0 \pm 0.06 \mathrm{~g}$ y $24.70 \pm 0.32 \mathrm{~g}$ para los tratamientos de agua de mar y agua dulce, respectivamente, con 4 repeticiones por tratamiento. Al finalizar el experimento los peces alcanzaron un peso de $161.80 \pm 12.78 \mathrm{~g}$ y $167.60 \pm 7.29 \mathrm{~g}$, respectivamente. El coeficiente térmico de crecimiento fue de 0.91 y 0.89 (agua de mar vs agua dulce), y no se observaron diferencias significativas. Sin embargo, la digestibilidad aparente tanto en materia seca como por nutriente (proteína, lípidos y carbohidratos) resultó significativamente mayor para los organismos en agua de mar. La digestibilidad pudiera estar asociada a una mayor actividad enzimática en presencia de una fuerza iónica mayor. El estudio de respirometría indicó que la relación O:N fue similar entre los organismos en agua de mar y los organismos en agua dulce, con valores de 21 y 18 , respectivamente. Lo anterior sugiere que esta variedad de tilapia presenta un catabolismo combinado de proteínas y lípidos como sustratos de energía. Se concluye que esta variedad de tilapia puede adaptarse y desarrollarse en un ambiente marino, lo cual puede contribuir a ampliar su forma de producción.

Palabras clave: tilapia híbrida, agua de mar, crecimiento, relación O:N, sustrato metabólico. 


\section{INTRODUCTION}

Tilapia is the generic term for several genera and species of the family Cichlidae, of which Oreochromis is important for aquaculture. Tilapias are assumed to have evolved from a marine ancestor and several varieties are euryhaline and thus able to tolerate and adapt to different salinity conditions (El-Sayed 2006). The temperature increases, altered rainfall regimes, and competition for freshwater between agricultural and urban sectors associated with global climate change have instigated studies on tilapia culture in estuarine and coastal environments (Prunet and Bornancin 1989, Romana-Eguia and Eguia 1999, Mena-Herrera et al. 2002, El-Sayed 2006, Fraga et al. 2012). Because of zootechnical characteristics such as hardiness, acceptance of a wide variety of food, high feed conversion, and ability to reproduce year-round (Lupchinski et al. 2011), tilapia is the second most important group of farmed fish in the world and considered to have the best potential for commercial culture in the 21 st century (Fitzsimmons 2010). Interest in tilapia culture in seawater in arid areas and near the coast arose in order to find another source of protein for human consumption (Cabrera et al. 2001). These fish are herbivorous and omnivorous, which favors the use of ingredients of plant origin in their culture because of their high digestibility of proteins, carbohydrates, and energy (Shiau and Huang 1989, Davies et al. 2011). Their high lipogenic activity is associated with their catabolic ability to metabolize carbohydrates (Qiang et al. 2014). In regions where the availability of freshwater for aquaculture is limited, tilapia farming in marine environments is of interest from a scientific and commercial point of view (Pang 2005/06, El-Sayed 2006), since there is growing demand for this fish.

The growth rates and feed conversion ratios of tilapia species such as Oreochromis aureus, Oreochromis spilurus, and hybrids reared in seawater are comparable to those of tilapia reared in freshwater (Cruz et al. 1990, MartínezContreras 2003). The results of an intensive culture of hybrid tilapia (Oreochromis niloticus $\times$ O. aureus) in floating cages in the Barra de Navidad lagoon system (Jalisco, Mexico) indicate that the culture of this hybrid in seawater for commercial purposes is feasible (Martínez-Contreras 2003). Though there are several comparative studies on the culture of tilapia species and hybrids in seawater and freshwater (Iwama et al. 1997, Mena-Herrera et al. 2002, Kamal and Mair 2005, Cnaani and Hulata 2011), the performance efficiency of the red tilapia hybrid Oreochromis mossambicus $\times O$. aureus has not been well studied. Therefore, the objective of the present study was to determine the growth perfomance, survival, and oxygen:nitrogen $(\mathrm{O}: \mathrm{N})$ ratio as an indicator of the metabolic substrate of the tilapia hybrid $O$. mossambicus $\times O$. aureus cultured in seawater and freshwater.

\section{INTRODUCCIÓN}

El término genérico tilapia se utiliza para describir a varios géneros y especies de peces de la familia Cichlidae, dentro de los cuales Oreochromis es de importancia para fines de acuacultura. Se cree que las tilapias evolucionaron de un ancestro marino y diversas variedades de tilapia son eurihalinas, por lo cual muestran capacidad para tolerar y adaptarse a diferentes condiciones de salinidad (El-Sayed 2006). Algunas consecuencias del cambio climático global como el aumento en la temperatura, la reducción del régimen de lluvias y la competencia por el agua dulce entre los sectores agrícolas y urbanos han promovido estudios para cultivar tilapia en ambientes estuarinos y costeros (Prunet y Bornancin 1989, Romana-Eguia y Eguia 1999, Mena-Herrera et al. 2002, El-Sayed 2006, Fraga et al. 2012). A nivel mundial, el cultivo de tilapia es el segundo más importante dentro de los cultivos de peces y se le considera como el cultivo con mayor potencial de crecimiento en la acuacultura en el siglo XXI (Fitzsimmons 2010). Lo anterior se relaciona con características zootécnicas para la tilapia, como alta rusticidad, aceptación de una variedad amplia de alimentos, alta conversión alimenticia y capacidad de reproducción a lo largo del año (Lupchinski et al. 2011). El interés por el cultivo de tilapia en agua de mar en zonas áridas y sobre todo cerca de la costa se desarrolló para proveer una fuente alternativa de proteína para alimentación humana (Cabrera et al. 2001). Estos peces son herbívoros y omnívoros, lo cual favorece el uso de ingredientes de origen vegetal en los cultivos ya que presentan una alta digestibilidad de proteínas, carbohidratos y energía (Shiau y Huang 1989, Davies et al. 2011). Además, muestran una actividad lipogénica alta, la cual se asocia con la capacidad catabólica para metabolizar carbohidratos (Qiang et al. 2014). En regiones donde la disponibilidad de recursos y cuerpos de agua dulce para uso acuícola es limitada, el cultivo de tilapia en ambientes marinos es de interés desde el punto de vista científico y comercial (Pang 2005/06, El-Sayed 2006), ya que la demanda en el mercado es cada vez más creciente.

Las especies de tilapia como Oreochromis aureus, Oreochromis spilurus e híbridos cultivadas en agua de mar pueden presentar tasas de crecimiento y conversión alimenticia comparables a las de tilapias cultivadas en agua dulce (Cruz et al. 1990, Martínez-Contreras 2003). Los resultados de un cultivo intensivo de tilapia hibrida (Oreochromis niloticus $\times$ O. aureus) en jaulas flotantes en la Laguna de Barra de Navidad (costa de Jalisco, México) indican que el cultivo de este híbrido en agua de mar para fines comerciales puede ser factible (Martínez-Contreras 2003). Aunque existen diversos estudios comparativos sobre el cultivo de especies de tilapia e híbridos en agua de mar y agua dulce (Iwama et al. 1997, Mena-Herrera et al. 2002, Kamal y Mair 2005, Cnaani y Hulata 2011), no se ha desarrollado un trabajo para evaluar a detalle la eficiencia y el desempeño de la tilapia roja híbrida Oreochromis mossambicus $\times$ O. aureus. El 


\section{MATERIALS AND METHODS}

A batch of 3000 juvenile hybrid red tilapia (O. mossambicus $\times$ O. aureus) was obtained from the Centro Acuícola de Zacatepec, Morelos, Mexico (Comisión Nacional de Pesca). The already masculinized fish were transported by plane to our laboratory. Half of the organisms were acclimated from freshwater to seawater by daily increments of 5 in salinity until a final concentration of 34.5. Acclimated and nonacclimated individuals of a similar weight $(24.9 \pm 0.2 \mathrm{~g}$ on average) were selected and distributed in groups of 50 in two culture systems, each one with four 500-L fiberglass tanks. Each tank constituted the experimental unit. Each culture system was connected to a biofilter coupled to a reservoir recirculation system in order to renew $5 \%$ of the water volume every day. Water temperature was maintained at $28.0 \pm 1{ }^{\circ} \mathrm{C}$ using a heater $(6500 \mathrm{~W})$ in each reservoir. Water quality variables (ammonium, nitrite, nitrate, carbonate, and $\mathrm{pH}$ levels) were evaluated twice a week in each culture system using a commercial test kit (Aquarium Pharmaceutical, Inc., Canada). Fish were fed to apparent satiation four times a day for 90 days. The diet was formulated based on their requirements to contain $40.2 \%$ crude protein and $8.5 \%$ crude fat (table 1). Growth performance (i.e., weight gain) was evaluated in each experimental unit every 30 days.

The following biological indices were calculated: thermal growth coefficient (according to Jobling 2003) $=1000 \times$ ((final weight ${ }^{1 / 3}-$ initial weight $\left.^{1 / 3}\right) / \Sigma$ (days $\times$ temperature)); protein efficiency ratio $=$ body weight gain/consumed protein; feed intake $=$ food consumed $\times 100 /$ [final weight + initial weight]/2)/days; feed conversion efficiency $=$ body weight gain/food consumed; and feed conversion ratio = food consumed/body weight gain.

The apparent digestibility coefficients of the dietary nutrients were evaluated by determining the acid-insoluble ash content in the diet and in the feces according to the method proposed by Tejada (1992) and modified by Montaño-Vargas et al. (2002). Proximate analyses of the experimental diet and feces were performed following standard methods (AOAC 1995). The nitrogen-free extract was determined by difference (Jobling 2001).

At the end of the study, respiration chambers were used to analyze oxygen consumption and ammonium excretion of one randomly-chosen fish from each treatment and experimental unit in the postpandrial state as reported by BarretoCuriel (2012). The O:N atomic ratio was calculated according to Handa et al. (2013) as follows: O:N = ([oxygen consumed $] / 16) /([$ ammonium excreted $] / 14)$.

Student's $t$ test for independent samples was used to estimate possible significant differences between the biological indices and the respirometric parameters of the experimental treatments. The differences were considered statistically significant if $P<0.05$. All statistical analyses were performed using SigmaStat 3.5 (Systat Software, Inc., Chicago, IL, USA). presente estudio se desarrolló con el propósito de determinar los índices de crecimiento, la supervivencia y la relación metabólica oxigeno:nitrógeno $(\mathrm{O}: \mathrm{N})$ como indicadora del sustrato energético en el híbrido de tilapia $O$. mossambicus $\times$ $O$. aureus cultivado en agua de mar y en agua dulce.

\section{MATERIALES Y MÉTODOS}

Se obtuvo un lote de 3000 juveniles de tilapia híbrida roja (O. mossambicus $\times$ O. aureus) procedente del Centro Acuícola de Zacatepec, Morelos, México (Comisión Nacional de Pesca). Los peces ya masculinizados fueron transportados en avión al laboratorio de acuacultura de la UABC. La mitad de los organismos fue sujeta a una aclimatación de agua dulce a agua de mar, mediante incrementos de 5 de salinidad por día hasta alcanzar una concentración final de 34.5. Posteriormente, se seleccionaron peces aclimatados y no aclimatados con un peso similar (promedio $24.9 \pm 0.2 \mathrm{~g}$ ) y se distribuyeron en grupos de 50 organismos en dos sistemas de cultivo, cada uno con cuatro estanques de fibra de vidrio con capacidad individual de 500 L. Cada estanque constituyó la unidad experimental. Cada sistema de cultivo estuvo conectado a un biofiltro acoplado a un sistema de recirculación con un estanque reservorio para renovar el 5\% del volumen de agua por día. La temperatura en los sistemas fue controlada a $28.0 \pm 1{ }^{\circ} \mathrm{C}$ mediante el uso un calentador $(6500 \mathrm{~W})$ en cada estanque reservorio. Los parámetros de la calidad del agua (amonio, nitritos, nitratos, carbonatos y $\mathrm{pH}$ ) en cada sistema de cultivo fueron evaluados dos veces por semana mediante el uso de un kit comercial (Aquarium Pharmaceutical, Inc., Canada). Los peces fueron alimentados hasta la saciedad aparente cuatro veces al día durante 90 días. La dieta fue formulada con base en sus requerimientos para contener $40.2 \%$ de proteína cruda y $8.5 \%$ de grasa cruda (tabla 1 ). El crecimiento en peso en cada unidad experimental se evaluó cada 30 días.

Se determinaron los siguientes índices biológicos: coeficiente térmico de crecimiento (de acuerdo con Jobling $2003)=1000 \times\left(\left(\right.\right.$ peso final $^{1 / 3}-$ peso inicial $\left.{ }^{1 / 3}\right) / \Sigma($ días $\times$ temperatura)); relación de eficiencia proteínica $=$ aumento de peso corporal/proteína consumida; ingestión de alimento $=$ alimento consumido $\times 100 /[$ peso final + peso inicial] $/ 2$ )/días; eficiencia de conversión alimenticia $=$ aumento de peso corporal/alimento consumido; y tasa de conversión alimenticia $=$ alimento consumido/aumento de peso corporal .

Los coeficientes de digestibilidad aparente de nutrientes del alimento se evaluaron mediante la determinación del contenido de cenizas insolubles en ácido en el alimento y en las heces de acuerdo con el método de Tejada (1992) modificado por Montaño-Vargas et al. (2002). El análisis proximal de la dieta experimental y de las heces se realizó de acuerdo con métodos estándar (AOAC 1995). El extracto libre de nitrógeno se determinó por diferencia (Jobling 2001).

Al final del estudio se analizó en cámaras respirométricas el consumo de oxígeno y excreción de amonio en un pez de 


\section{RESULTS}

After 90 days of the experiment, survival in both culture treatments was $99.5 \%$ (table 2). There were no significant differences $(P>0.05)$ in weight gain and thermal growth coefficient between the fish cultured in seawater and freshwater (table 2). Likewise, the protein efficiency ratio, feed intake, feed conversion efficiency, and feed conversion ratio did not differ significantly between the treatment groups. The individuals cultured in seawater had the highest digestibility values for dietary dry matter, protein, lipids, and carbohydrates. No significant differences $(P>0.05)$ in oxygen consumption, ammonium excretion, and $\mathrm{O}: \mathrm{N}$ ratio were observed between the treatment groups (table 3 ).

\section{DISCUSSION}

All tilapia are freshwater fish but their euryhaline ability allows several species and hybrids to adapt and develop in

Table 1. Ingredients $(\mathrm{g} / 100 \mathrm{~g}$ diet $)$ and proximate composition $(\mathrm{g} / 100 \mathrm{~g})$ of the diet.

Tabla 1. Ingredientes ( $\mathrm{g} / 100 \mathrm{~g}$ dieta) y composición proximal $(\mathrm{g} / 100 \mathrm{~g})$ de la dieta.

\begin{tabular}{|c|c|}
\hline \multicolumn{2}{|l|}{ Ingredient } \\
\hline Corn starch & 32.02 \\
\hline Fishmeal $^{\mathrm{a}}$ & 21.00 \\
\hline Poultry by-product meal ${ }^{\mathrm{b}}$ & 21.00 \\
\hline Soybean meal ${ }^{\mathrm{c}}$ & 7.00 \\
\hline Gelatin & 6.00 \\
\hline Corn meal $^{\mathrm{d}}$ & 5.50 \\
\hline Fish oil & 3.75 \\
\hline Vitamin and mineral mixture ${ }^{e}$ & 3.00 \\
\hline Stay-C & 0.40 \\
\hline Sodium benzoate & 0.23 \\
\hline Choline chloride & 0.09 \\
\hline Tocopherol & 0.01 \\
\hline \multicolumn{2}{|c|}{ Proximate composition ( $\%$ dry matter basis) } \\
\hline Crude protein & 40.2 \\
\hline Crude fat & 8.5 \\
\hline Ash & 10.5 \\
\hline Carbohydrate $^{\mathrm{f}}$ & 40.8 \\
\hline Gross energy $(\mathrm{kJ} / \mathrm{g})$ & 19.9 \\
\hline
\end{tabular}

a Tuna meal: $60 \%$ crude protein, $6.9 \%$ crude fat.

${ }^{\mathrm{b}}$ Pet food grade: $65 \%$ crude protein, $12 \%$ crude fat.

c $42 \%$ crude protein, $1.0 \%$ crude fat.

d $8 \%$ crude protein, $3.9 \%$ crude fat.

${ }^{\text {e }}$ Donated by DSM, Guadalajara, Mexico.

${ }^{\mathrm{f}}$ Calculated by difference as nitrogen free extract + fiber. cada tratamiento y unidad experimental, elegido al azar y en estado postpandrial según lo reportado por Barreto-Curiel (2012). La relación atómica O:N se calculó de acuerdo con Handa et al. (2013) como sigue: O:N = ([oxígeno consumido $] / 16) /([$ amonio excretado $] / 14)$.

Para estimar las posibles diferencias significativas entre los índices biológicos y los parámetros de la respirometría en los tratamientos experimentales, se utilizó la prueba $t$ de Student para muestras independientes. Las diferencias fueron consideradas estadísticamente significativas si $P<0.05$. Los análisis estadísticos se realizaron con el programa SigmaStat 3.5 (Systat Software, Inc., Chicago, IL, EUA).

\section{RESULTADOS}

Al término de los 90 días del ensayo, la supervivencia en ambos tratamientos experimentales fue de $99.5 \%$ (tabla 2 ). No hubieron diferencias significativas $(P>0.05)$ en el incremento en peso y la tasa de conversión alimenticia entre los peces cultivados en agua de mar y en agua dulce (tabla 2). Así mismo, la relación de eficiencia proteínica, la ingestión del alimento, la eficiencia de conversión y la tasa de

Table 2. Biological indices of juvenile hybrid tilapia (Oreochromis mossambicus $\times$ Oreochromis aureus) after being fed an experimental diet for 90 days in seawater and freshwater (mean \pm standard deviation).

Tabla 2. Índices biológicos de los juveniles híbridos de tilapia roja (Oreochromis mossambicus $\times$ Oreochromis aureus) después de haber sido alimentados durante 90 días en agua de mar y en agua dulce (media \pm desviación stándar).

\begin{tabular}{lcc}
\hline Biological index & Seawater & Freshwater \\
\hline Initial weight (g) & $25.00 \pm 0.06$ & $24.70 \pm 0.32$ \\
Final weight (g) & $161.80 \pm 12.78$ & $167.60 \pm 7.29$ \\
Weight gain (\%) & $643.51 \pm 54.05$ & $672.11 \pm 17.92$ \\
TGC $^{\mathrm{a}}$ & $0.93 \pm 0.03$ & $0.89 \pm 0.02$ \\
PER $^{\mathrm{b}}$ & $1.97 \pm 0.12$ & $2.08 \pm 0.07$ \\
FI $^{\mathrm{c}}$ & $1.34 \pm 0.08$ & $1.28 \pm 0.04$ \\
FCE $^{\mathrm{d}}$ & $0.82 \pm 0.05$ & $0.86 \pm 0.03$ \\
FCR $^{\mathrm{e}}$ & $1.22 \pm 0.07$ & $1.20 \pm 0.03$ \\
Survival (\%) & 99.5 & 99.5 \\
Digestibility & & \\
Dry matter* & $83.86 \pm 0.88$ & $71.35 \pm 0.93$ \\
Protein* & $79.38 \pm 0.02$ & $65.56 \pm 1.55$ \\
Lipid* & $77.50 \pm 1.66$ & $67.00 \pm 0.65$ \\
\hline
\end{tabular}

${ }^{\mathrm{a}} \mathrm{TGC}=$ thermal growth coefficient.

${ }^{\mathrm{b}} \mathrm{PER}=$ protein efficiency ratio.

${ }^{\mathrm{c}} \mathrm{FI}=$ feed intake.

${ }^{\mathrm{d}} \mathrm{FCE}=$ feed conversion efficiency.

${ }^{\mathrm{e}} \mathrm{FCR}=$ feed conversion ratio.

* Means in the same row are significantly different $(P<0.05)$. 
brackish and marine waters (Kamal and Mair 2005). In this study, the culture of hybrid red tilapia (O. mossambicus $\times O$. aureus) in seawater and freshwater did not reveal significant differences in either growth performance or the biological indices evaluated after 90 days. The growth performance was similar to that reported for hybrid tilapia (O. mossambicus $\times$ $O$. niloticus) fingerlings reared in seawater and freshwater and fed a commercial pelleted diet ad libitum for eight weeks (Martínez-Contreras 2003). The hybrid O. mossambicus $\times O$. aureus shows high tolerance to salinity and can grow normally in seawater (El-Sayed 2006). A significant positive correlation between relative weight gain and increased salinity was reported for the hybrid $O$. mossambicus $\times O$. niloticus (Kamal and Mair 2005), a tendency that we did not observe in this study. In Florida red tilapia (O. mossambicus $\times O$. urolepis hornorum), an increase in salinity promotes greater feed intake (Watanabe et al. 1988). This behavior was not observed in the present study because feed intake did not differ significantly between treatment groups.

In the case of euryhaline fish such as tilapia, their culture in seawater, because of osmoregulation, is assumed to affect the activity of digestive enzymes and influence the feed conversion ratio and efficiency (Rubio et al. 2005, Ridha 2015); however, this was not observed in the present study. It has been suggested that fish growth in saline environments is associated with osmoregulation and the expression of proteins such as transferrin (Rengmark and Lingaas 2007), the ability to adapt their feed intake to the environmental salinity conditions, the metabolic rate, and endocrine factors (Prunet and Bornancin 1988, Boeuf and Payan 2001). Our digestibility values for dry matter, proteins, and lipids differed relative to the culture medium. In relation to the effect of salinity on changes in digestive enzymatic activity and nutrient digestibility in fish (Moutou et al. 2004, Rubio et al. 2005), in the hybrid $O$. mossambicus $\times O$. niloticus the activity of trypsine and $\alpha$-amylase increases with salinity (Sandoval-Muy et al. 2012). This is related to a possible activation of zymogens in the intestinal lumen (Moutou et al. 2004). A recent study (in preparation) on the characterization of lipases in our laboratory revealed that in the anadromous striped bass (Morone saxatilis), the activity of lipase increased in the presence of $\mathrm{NaCl}$; this does not occur in the Pacific bluefin tuna (Thunnus orientalis) and totoaba (Totoaba macdonaldi), species that conversión alimenticia no presentaron diferencias significativas entre los tratamientos de cultivo. Los peces cultivados en agua de mar presentaron los mayores valores de digestibilidad de la materia seca, proteína, lípidos y carbohidratos del alimento formulado. El consumo de oxígeno, la excreción de amonio y la relación metabólica O:N no presentaron diferencia significativa $(P>0.05)$ entre ambas condiciones de cultivo (tabla 3 ).

\section{DISCUSIÓN}

Todas las especies de tilapia son de origen dulceacuícola pero su capacidad eurihalina permite que varias especies e híbridos puedan adaptarse y desarrollarse en aguas salobres y en agua de mar (Kamal y Mair 2005). En el presente estudio el cultivo de la tilapia hibrida roja (O. mossambicus $\times$ O. aureus) en agua de mar y en agua dulce no mostró diferencias significativas en el desempeño tanto en crecimiento en peso como en los índices biológicos evaluados al término de 90 días. Este comportamiento en el crecimiento es similar al determinado en alevines del híbrido O. mossambicus $\times O$. niloticus cultivados en agua de mar y en agua dulce y alimentados ad libitum con alimento comercial peletizado durante ocho semanas (Martínez-Contreras 2003). El híbrido de $O$. mossambicus $\times O$. aureus presenta una alta tolerancia a la salinidad, lo cual le permite crecer en forma normal en agua de mar (El-Sayed 2006). Respecto al híbrido de O. mossambicus $\times$ O. niloticus, se ha reportado una correlación significativamente positiva en el aumento relativo del peso con el incremento en la salinidad (Kamal y Mair 2005), tendencia que no se determinó en el híbrido de nuestro estudio. En la tilapia roja de Florida (O. mossambicus $\times O$. urolepis hornorum) el incremento de la salinidad del medio promueve un mayor consumo de alimento (Watanabe et al. 1988), comportamiento que no se presentó en este estudio ya que la ingestión de alimento no difirió significativamente entre los tratamientos en agua de mar y en agua dulce.

En el caso de peces eurihalinos como la tilapia, se presume que su cultivo en agua de mar, debido a la osmoregulación, puede afectar la actividad de sus enzimas digestivas e influir en la eficiencia y la tasa de conversión alimenticia (Rubio et al. 2005, Ridha 2015); sin embargo, esto no se

Table 3. Oxygen consumption, ammonium excretion, and oxygen:nitrogen $(\mathrm{O}: \mathrm{N})$ ratio of juvenile hybrid tilapia (Oreochromis mossambicus $\times$ Oreochromis aureus) grown in seawater and freshwater (mean \pm standard deviation).

Tabla 3. Consumo de oxígeno, excreción de amonio y razón oxígeno:nitrógeno (O:N) de juveniles híbridos de tilapia roja (Oreochromis mossambicus $\times$ Oreochromis aureus) cultivados en agua de mar y en agua dulce (media \pm desviación stándar).

\begin{tabular}{lccc}
\hline Culture & $\begin{array}{c}\text { Oxygen consumed } \\
\left(\mu \mathrm{g} \mathrm{O}_{2} / \mathrm{h} / \mathrm{g} \text { wet weight }\right)\end{array}$ & $\begin{array}{c}\text { Ammonium excretion } \\
(\mu \mathrm{g} \mathrm{NH} / \mathrm{h} / \mathrm{g} \text { wet weight })\end{array}$ & $\mathrm{O}: \mathrm{N}$ ratio \\
\hline Seawater & $271 \pm 22$ & $12 \pm 4.3$ & $21.2 \pm 6.4$ \\
Freshwater & $387 \pm 48$ & $20 \pm 7.7$ & $18.2 \pm 5.3$ \\
\hline
\end{tabular}


are completely catadromous. Additional studies on the effect of salinity on the digestibility of dietary macronutrients and energy in the hybrid red tilapia are needed to be able to optimize its nutrition and culture in saline environments.

The O:N ratio is an indicator of the main substrate used by organisms to produce energy aerobically. Values of 3-16 indicate the catabolism of proteins, values of 16-60 indicate the combined used of proteins and lipids as substrates, and values $>60$ indicate that lipids are the predominant source of energy (Langenbuch and Pörtner 2002, Tseng and Hwang 2008). In this study, the O:N values obtained for hybrid red tilapia reared in seawater and freshwater suggest a combined use of proteins and lipids as energy substrates in both treatments, which indicates that the difference in salinity did not significantly affect the type of metabolic substrate used as the predominant source of energy. This behavior is similar to that reported for Sphoeroides annulatus. This species was exposed to a variation in salinity of 31 and no significant differences were observed in the O:N atomic ratio and its main source of metabolic energy (Pérez-Robles et al. 2012).

The red tilapia hybrid $O$. mossambicus $\times O$. aureus is considered to have high potential for cultivation in a marine environment because of its high salinity tolerance, adaptation to confinement with high survival, rapid growth, and attractive sensory characteristics such as agreeably-tasting meat and a similar color to that of snappers (Fraga et al. 2012). Our results show that it is feasible to cultivate this hybrid species in seawater and obtain a growth performance similar to that achieved in freshwater. We conclude that this strain of tilapia has the ability to adapt and thrive in a marine environmment and that its farming practices could be expanded.

\section{ACKNOWLEDGMENTS}

This study was financed by the UABC through project $403 / 1 / C / 19 / 15$. We thank CONAPESCA for the help provided in obtaining the organisms; the students, in particular Daniel Badillo Zapata, who lent assistance during the experiment; and Jorge Hernandez.

English translation by Christine Harris.

\section{REFERENCES}

[AOAC] Association of Official Analytical Chemists. 1995. Official Methods of Analysis of AOAC International Vol. 1. AOAC International, Arlington, VA, $684 \mathrm{pp}$.

Barreto-Curiel F. 2012. Validación y estandarización de cámaras respirométricas para evaluar el consumo de oxígeno y excreción de amonio en tilapia (Oreochromis niloticus var. Spring) bajo condiciones de estrés. MSc thesis, Universidad Autónoma de Baja California, México, 69 pp.

Boeuf G, Payan P. 2001. How should salinity influence fish growth? Comp. Biochem. Physiol. 131C: 411-423.

Cabrera T, Millán J, Rosas J, Rengel J. 2001. Cultivo del híbrido de tilapia en un ambiente marino, sustituyendo harinas de pescado por soya. Cienc. Pesq. 15: 121-125. denotó en el periodo de estudio. Se ha sugerido que el crecimiento de peces en ambientes salinos está asociado con la osmoregulación y la expresión de proteínas como la transferina (Rengmark y Lingaas 2007), la capacidad para adaptar la ingesta de alimento a la condiciones de salinidad del medio, la tasa metabólica y los factores endocrinos (Prunet y Bornancin 1988, Boeuf y Payan 2001). En nuestro estudio los valores de la digestibilidad del alimento, proteínas y lípidos presentaron diferencias con relación al medio de cultivo. Con relación al efecto de la salinidad sobre cambios en la actividad enzimática digestiva y la digestibilidad de nutrientes en peces (Moutou et al. 2004, Rubio et al. 2005), se ha reportado que en el hibrido $O$. mossambicus $\times O$. niloticus la actividad de tripsina y $\alpha$-amilasa se incrementa con la salinidad (Sandoval-Muy et al. 2012). Lo anterior se asocia a una posible activación de zimógenos en el lumen intestinal (Moutou et al. 2004). En un estudio reciente (en preparación) sobre caracterización de lipasas en nuestro laboratorio se determinó que en la lobina rayada (Morone saxatilis), especie anádroma, la lipasa incrementa su actividad en presencia de $\mathrm{NaCl}$; esto es algo que no ocurre con el atún aleta azul (Thunnus orientalis) y la totoaba (Totoaba macdonaldi) que son peces meramente catádromos. Estudios posteriores sobre la interacción de la salinidad en la digestibilidad de macronutrientes y energía de la dieta en la tilapia hibrida roja permitirán optimizar su nutrición y cultivo en ambientes salinos.

La relación O:N es un indicador del sustrato principal que es utilizado por los organismos vía aeróbica para obtener energía, donde valores de 3 a 16 se asocian con el catabolismo de proteínas, valores de 16 a 60 se relacionan con el uso combinado de proteínas y lípidos como sustratos, y valores mayores que 60 se asocian con el predominio de lípidos como fuente de energía (Langenbuch y Pörtner 2002, Tseng y Hwang 2008). En este estudio los valores O:N obtenidos para la tilapia híbrida roja cultivada en agua de mar y en agua dulce sugieren un catabolismo combinado de proteínas y lípidos como sustratos de energía en ambos medios, lo cual denota que la diferencia de salinidad no presentó un efecto significativo en el tipo de sustrato metabólico utilizado como fuente principal de energía. Este comportamiento es semejante al registrado para Sphoeroides annulatus. Esta especie fue sometida a una variación de salinidad de 31 y no se observó una diferencia significativa en la relación atómica $\mathrm{O}: \mathrm{N}$ y en su principal fuente de energía metabólica (PérezRobles et al. 2012).

La tilapia hibrida roja (O. mossambicus $\times O$. aureus $)$ es considerada que tiene alto potencial para su cultivo en ambiente marino, por su tolerancia a alta salinidad, adaptación al confinamiento con supervivencia elevada y crecimiento acelerado, así como por características sensoriales atractivas como la coloración similar a la del pargo y el buen sabor de su carne (Fraga et al. 2012). Los resultados del presente estudio indican que es factible cultivar esta especie 
Cnaani A, Hulata G. 2011. Improving salinity tolerance in tilapias: Past experience and future prospects. Isr. J. Aquacult./Bamidgeh 63: 1-21.

Cruz EM, Ridha M, Adullah MS. 1990. Production of African freshwater tilapia Oreochromis spilurus (Günther) in seawater. Aquaculture 84: 41-48.

Davies SJ, Abdel-Warith AA, Gouveia A. 2011. Digestibility characteristics of selected feed ingredients for developing bespoke diets for Nile tilapia culture in Europe and North America. J. World Aquacult. Soc. 42(3): 388-398. http://dx.doi.org/10.1111/j.1749-7345.2011.00478.x

El-Sayed A-F M. 2006. Tilapia culture in salt water: Environmental requirements, nutritional implications and economic potentials. In: Cruz SLE, Ricque MD, Tapia SM, Nieto LM, Villareal CD, Puello CA, García OA (eds.), Avances en Nutrición Acuícola. VIII. Simposium Internacional de Nutrición Acuícola, 15-17 Noviembre, Universidad Autónoma de Nuevo León, Monterrey, México, pp. 95-106.

Fitzsimmons K. 2010. Potential to Increase Global Tilapia Production. Global Outlook for Aquaculture Leadership, Kuala Lumpur, $35 \mathrm{pp}$.

Fraga I, Flores ER, Reyes R, Llanes Y. 2012. Efecto de diferentes densidades de siembra en el engorde de tilapia roja (Oreochromis mossambicus $\times$ O. aureus) en jaulas colocadas en la bahía de Casilda, Cuba. Rev. Invest. Mar. 32(1): 16-23.

Jobling M. 2001. Nutrient partitioning and the influence of feed composition on body composition. In: Houlihan D, Boujard T, Jobling M (eds.), Food Intake in Fish. Blackwell Science, Oxford, pp. 354-375.

Jobling M. 2003. The thermal growth coefficient (TGC) model of fish growth: A cautionary note. Aquacult. Res. 34: 581-584.

Handa A, Nordtug T, Halstensen S, Olsen AJ, Reitan KI, Olsen Y, Reinertsen H. 2013. Temperature-dependent feed requirements in farmed blue mussels (Mytilus edulis L.) estimated from soft tissue growth and oxygen consumption and ammonia-N excretion. Aquacult. Res. 44(4): 645-656. http://dx.doi.org/10.1111/j.1365-2109.2011.03069.x

Iwama GK, Takemura A, Takano K. 1997. Oxygen consumption rates of tilapia in fresh water, sea water, and hypersaline sea water. J. Fish Biol. 51: 886-894.

Kamal AHMM, Mair GC. 2005. Salinity tolerance in superior genotypes of tilapia, Oreochromis niloticus, Oreochromis mossambicus and their hybrids. Aquaculture 247(1-4): 189-201. http://dx.doi.org/10.1016/j.aquaculture.2005.02.008

Langenbuch M, Pörtner HO. 2002. Changes in metabolic rate and N excretion in the marine invertebrate Sipunculus nudus under conditions of environmental hypercapnia: Identifying effective acid-base variables. J. Exp. Biol. 205: 1153-1160.

Lupchinski Jr E, Vargas L, Lopera-Barrero NM, Ribeiro RP, Povh JA, Gasparino E, Gomes PC, Braccini GL. 2011. Caracterización genética de tres líneas de tilapia del Nilo (Oreochromis niloticus). Arch. Zootec. 60(232): 985-995.

Martínez-Contreras TM. 2003. Adaptación y crecimiento de las tilapias Oreochromis niloticus, Oreochromis aureus, Oreochromis niloticus $\times$ Oreochromis aureus en agua salada. $\mathrm{PhD}$ thesis, Universidad de Colima, México, $95 \mathrm{pp}$.

Mena-Herrera A, Sumano-López H, Macías-Zamora R. 2002. Efecto de la salinidad en el crecimiento de tilapia híbrida Oreochromis mossambicus (Peters) $\times$ Oreochromis niloticus (Linnaeus), cultivadas bajo condiciones de laboratorio. Vet. Mex. 33(1): 39-48.

Montaño-Vargas J, Shimada A, Vásquez C, Viana MT. 2002. Methods of measuring feed digestibility in the green abalone (Haliotis fulgens). Aquaculture 213: 339-346. híbrida en agua de mar con un desempeño en crecimiento similar al que se obtiene en agua dulce. Lo anterior denota la capacidad de la tilapia híbrida roja para adaptarse y desarrollarse en el medio marino, lo cual puede contribuir a ampliar su forma de producción.

\section{AgRadecimientos}

Este proyecto fue financiado por la UABC a través del proyecto 403/1/C/19/15. Agradecemos a la CONAPESCA el apoyo brindado para la obtención de los organismos. También queremos agradecer a los estudiantes de servicio social, a Jorge Hernández y en especial a Daniel Badillo Zapata, estudiante de doctorado.

Moutou KA, Panagiotaki P, Mamuris Z. 2004. Effects of salinity on digestive protease activity in the euryhaline sparid Sparus aurata L.: A preliminary study. Aquacult. Res. 35(9): 912-914. http://dx.doi.org/10.1111/j.1365-2109.2004.01068.x

Pang KC. 2005/06. Production of marine tilapia hybrid for culture in a coastal fish farm. Singapore J. Primary Ind. 32: 93-105.

Pérez-Robles J, Re AD, Giffard-Mena I, Díaz F. 2012. Interactive effects of salinity on oxygen consumption, ammonium excretion, osmoregulation and $\mathrm{Na}^{+} / \mathrm{K}^{+}$-ATPase expression in the bullseye puffer (Sphoeroides annulatus, Jenyns 1842). Aquacult. Res. 43(9): 1372-1383. http://dx.doi.org/10.1111/j.1365-2109.2011.02940.x

Prunet P, Bornancin M. 1989. Physiology of salinity tolerance in tilapia: An update of basic and applied aspects. Aquat. Living Resour. 2: 91-97.

Qiang J, Yang H, He J, Wang H, Zhu ZX, Xu P. 2014. Comparative study of the effects of two high-carbohydrate diets on growth and hepatic carbohydrate metabolic enzyme responses in juvenile gift tilapia (Oreochromis niloticus). Turk. J. Fish. Aquat. Sci. 14: 515-525.

http://dx.doi.org/10.4194/1303-2712-v14_2_23

Rengmark AH, Lingaas F. 2007. Genomic structure of the Nile tilapia (Oreochromis niloticus) transferrin gene and a haplotype associated with saltwater tolerance. Aquaculture 272(1-4): $146-155$. http://dx.doi.org/10.1016/j.aquaculture.2007.08.035

Ridha MT. 2015. Hybrid tilapia outperform pure-breds in seawater study. Global Aquaculture Advocate January/February 2015, pp. 66-67.

Romana-Eguia MRR, Eguia RV. 1999. Growth of five Asian red tilapia strains in saline environments. Aquaculture 173: 161-170.

Rubio VC, Sánchez-Vázquez FJ, Madrid JA. 2005. Effects of salinity on food intake and macronutrient selection in European sea bass. Physiol. Behav. 85(3): 333-339. http://dx.doi.org/10.1016/j.physbeh.2005.04.022

Sandoval-Muy MI, Guereña-Araiza MA, Miranda-Baeza A, RivasVega ME. 2012. Metabolismo de rutina y actividad enzimática digestiva en juveniles de tilapia (Oreochromis mossambicus $\times$ Oreochromis niloticus) aclimatada a diferentes salinidades. Biotecnia 14(2): 11-17.

Shiau S, Huang SSO. 1989. Optimal dietary protein level for hybrid tilapia (Oreochromis niloticus $\times$ Oreochromis aureus) reared in seawater. Aquaculture 81: 119-127. 
Tejada I. 1992. Control de Calidad y Análisis de Alimentos para Animales. Sistema de Educación Continua, AC, México, DF, $310 \mathrm{pp}$.

Tseng Y-C, Hwang P-P. 2008. Some insights into energy metabolism for osmoregulation in fish. Comp. Biochem. Physiol C 148(4): 419-429.

http://dx.doi.org/10.1016/j.cbpc.2008.04.009
Watanabe WO, Elligson, LJ, Wicklund RI, Olla BL. 1988. The effects of salinity on growth, food consumption and conversion in juvenile, monosex male Florida red tilapia. In: Pullin RSV, Bhukasswan T, Tonguthai K, Maclean JL (eds.), Proceedings of the Second International Symposium on Tilapia in Aquaculture. ICLARM Conference Proceedings 15, Department of Fisheries, Bangkok, Thailand, and International Center for Living Aquatic Resources Management, Manila, Philippines, pp. 515-523.

Received March 2015, accepted August 2015. 